\title{
Large-scale movements of common bottlenose dolphins in the Atlantic: dolphins with an international courtyard
}

\author{
Ana Dinis ${ }^{\text {Corresp., } 1,2}$, Carlota Molina $^{2,3}$, Marta Tobena ${ }^{4}$, Annalisa Sambolino ${ }^{1,2}$, Karin Hartman ${ }^{5}$, Marc Fernandez ${ }^{1,6}$, \\ Sara Magalhães $^{7}$, Rui Peres dos Santos ${ }^{8}$, Fabian Ritter ${ }^{9}$, Vidal Martín ${ }^{10}$, Natacha Aguilar de Soto ${ }^{11}$, Filipe Alves ${ }^{1,2}$ \\ 1 MARE-Marine and Environmental Sciences, Funchal, Madeira, Portugal \\ 2 OOM - Oceanic Observatory of Madeira, Funchal, Madeira, Portugal \\ 3 Department of Animal Biology, Ecology and Environmental Sciences, University of Barcelona, Barcelona, Catalonia, Spain \\ 4 Centro I\&D Okeanos, University of Azores, Horta, Azores, Portugal \\ 5 Risso's Dolphin Research Center, Nova Atlantis Foundation, Pico, Azores, Portugal \\ 6 CE3C - Centre for Ecology, Evolution and Environmental Changes/Azorean Biodiversity Group, University of Azores, Ponta Delgada, Azores, Portugal \\ 7 Mar llimitado, Sagres, Portugal \\ 8 Futurismo, Pico, Azores, Portugal \\ 9 MEER e.V, Berlin, Germany \\ 10 SECAC Society for the Study of Cetaceans in the Canary Archipelago, Lanzarote, Canary Island, Spain \\ 11 BIOECOMAC, Department of Animal Biology, University of La Laguna, Tenerife, Canary Island, Spain
}

Corresponding Author: Ana Dinis

Email address: ana.dinis@mare-centre.pt

Wide-ranging connectivity patterns of common bottlenose dolphins (Tursiops truncatus) are generally poorly known worldwide and more so within the oceanic archipelagos of Macaronesia in the North East (NE) Atlantic. This study aimed to identify long-range movements between the archipelagos of Macaronesia that lie between 500 and $1500 \mathrm{Km}$ apart, and between Madeira archipelago and the Portuguese continental shelf, through the compilation and comparison of bottlenose dolphin's photo-identification catalogues from different archipelagos: one from Madeira ( $n=363$ individuals), two from different areas in the Azores ( $n=495$ and 176), and four from different islands of the Canary Islands $(n=182$, 110, 142 and 281), summing up 1791 photographs. An additional comparison was made between the Madeira catalogue and one catalogue from Sagres, on the southwest tip of the Iberian Peninsula $(n=359)$. Results showed 26 individual matches, mostly between Madeira and the Canary Islands $(n=23)$, and between Azores and Madeira $(n=3)$. No matches were found between the Canary Islands and the Azores, and between Madeira and Sagres. There were no individuals identified in all three archipelagos. The minimum time recorded between sightings in two different archipelagos ( $\approx 460 \mathrm{Km}$ apart) was 62 days. Association patterns revealed that the individuals moving between archipelagos were connected to resident, migrant and transient individuals in Madeira. The higher number of individuals that were re-sighted between Madeira and the Canary Islands can be 
explained by the relative proximity of these two archipelagos. This study shows the first inter-archipelago movements of bottlenose dolphins in the Macaronesia region, emphasizing the high mobility of this species and supporting the high gene flow described for oceanic dolphins inhabiting the North Atlantic. The dynamics of these long-range movements strongly denotes the need to review marine protected areas established for this species in each archipelago, calling for joint resolutions from three autonomous regions belonging to two EU countries. 
1 Large-scale movements of common bottlenose dolphins in 2 the Atlantic: dolphins with an international courtyard

3

4

5

6 7 8

Ana Dinis ${ }^{1,2}$ Carlota Molina ${ }^{2,3}$, Marta Tobeña ${ }^{4}$, Annalisa Sambolino ${ }^{1,2}$, Karin Hartman ${ }^{5}$, Marc Fernandez ${ }^{1,6}$, Sara Magalhães ${ }^{7}$, Rui Peres dos Santos ${ }^{8}$, Fabian Ritter ${ }^{9}$, Vidal Martín ${ }^{10}$, Natacha Aguilar de Soto ${ }^{11}$, Filipe Alves ${ }^{1,2}$

${ }^{1}$ MARE - Marine and Environmental Sciences, Funchal, Madeira, Portugal

${ }^{2}$ OOM - Oceanic Observatory of Madeira, Funchal, Madeira, Portugal

${ }^{3}$ Department of Animal Biology, Ecology and Environmental Sciences, University of Barcelona, Barcelona, Spain

${ }^{4}$ Centro I\&D Okeanos, University of Azores, Horta, Azores, Portugal

${ }^{5}$ Nova Atlantis Foundation, Risso's Dolphin Research Center, Pico, Azores, Portugal

${ }^{6} \mathrm{cE} 3 \mathrm{c}$ - Centre for Ecology, Evolution and Environmental Changes /Azorean Biodiversity Group and University of Azores, Azores, Portugal

${ }^{7}$ Mar Ilimitado, Sagres, Portugal

${ }^{8}$ Futurismo, Pico, Portugal

${ }^{9}$ MEER e.V., Berlin, Germany

${ }^{10}$ SECAC Society for the Study of Cetaceans in the Canary Archipelago, Arrecife, Lanzarote, Spain

${ }^{11}$ BIOECOMAC, Department of Animal Biology, University of La Laguna, Tenerife, Spain

Corresponding Author:

Ana Dinis

Ed. Madeira Tecnopolo, Caminho da Penteada, Funchal, 9020-105, Madeira, Portugal

Email address: ana.dinis@mare-centre.pt

\section{Abstract}

Wide-ranging connectivity patterns of common bottlenose dolphins (Tursiops truncatus) are generally poorly known worldwide and more so within the oceanic archipelagos of Macaronesia in the North East (NE) Atlantic. This study aimed to identify long-range movements between the archipelagos of Macaronesia that lie between 500 and $1500 \mathrm{Km}$ apart, and between Madeira archipelago and the Portuguese continental shelf, through the compilation and comparison of bottlenose dolphin's photo-identification catalogues from different archipelagos: one from Madeira ( $n=363$ individuals), two from different areas in the Azores ( $n=495$ and 176), and four from different islands of the Canary Islands ( $\mathrm{n}=182,110,142$ and 281), summing up 1791 photographs. An additional comparison was made between the Madeira catalogue and one catalogue from Sagres, on the southwest tip of the Iberian Peninsula $(n=359)$. Results showed 26 
40

41

42

43

44

45

46

47

48

49

50

51

52

53

54

55

56

57

58

59

60

61

62

63

64

65

66

67

68

69

70

71

72

73

74

75

76

77

78

79

individual matches, mostly between Madeira and the Canary Islands $(n=23)$, and between Azores and Madeira $(n=3)$. No matches were found between the Canary Islands and the Azores, and between Madeira and Sagres. There were no individuals identified in all three archipelagos. The minimum time recorded between sightings in two different archipelagos $(\approx 460 \mathrm{Km}$ apart) was 62 days. Association patterns revealed that the individuals moving between archipelagos were connected to resident, migrant and transient individuals in Madeira. The higher number of individuals that were re-sighted between Madeira and the Canary Islands can be explained by the relative proximity of these two archipelagos. This study shows the first inter-archipelago movements of bottlenose dolphins in the Macaronesia region, emphasizing the high mobility of this species and supporting the high gene flow described for oceanic dolphins inhabiting the North Atlantic. The dynamics of these long-range movements strongly denotes the need to review marine protected areas established for this species in each archipelago, calling for joint resolutions from three autonomous regions belonging to two EU countries.

\section{Introduction}

The common bottlenose dolphin Tursiops truncatus, (hereafter "bottlenose dolphin"), like other cetaceans, faces a variety of anthropogenic disturbances, such as water pollution, incidental capture (by-catch) or vessel collisions (Wells \& Scott, 2018). Coastal and pelagic variations or ecotypes of bottlenose dolphins have been described based on morphological, ecological and genetic differences (Oudejans et al., 2015). The well-studied populations of coastal bottlenose dolphins exhibit a variety of horizontal movements, including seasonal migrations, year-around home ranges, periodic residency, and a combination of occasional long-range movements and repeated local residency (Shane, Wells \& Würsig, 1986; Wells \& Scott, 2018). However, much less is known about the ranging patterns of pelagic bottlenose dolphins (Wells \& Scott, 2018). It is crucial to gain a better understanding of the ranging patterns of this species in order to establish suitable conservation measures. Apart from small scale movements of bottlenose dolphin studied in greater depth (e.g. Reynolds, Wells and Eide., 2000; Silva et al., 2008; Tobeña et al., 2014; Hwang et al., 2014; Dinis et al., 2016), information from long-distance and inter-archipelagos movements is scarce. Insufficient information on long-distance movements may result in higher emphasis on residency (Bearzi, Bonizzoni \& Gonzalvo, 2011), when in fact individuals may leave the study area more frequently than initially thought. Previous studies of pelagic bottlenose dolphin populations in the NE Atlantic area suggested that these populations have a high gene flow and are genetically less differentiated (Querouil et al., 2007; Louis et al., 2014). Additionally, different residency patterns and individual movements within each archipelago were identified for the Azores (Silva et al., 2008), the Canary Islands (Tobeña et al., 2014) and Madeira (Dinis et al., 2016), with just a portion of the individuals being classified as residents. These results indicate large individual home ranges, but there is no evidence of the connectivity of the populations between these oceanic archipelagos. A recent photoidentification study demonstrated the connectivity of pilot whales within the Macaronesia 
80 biogeographical region (Alves et al., 2019), also highlighting the importance of such studies for 81 conservation. Hence, it can be speculated that other highly mobile species like bottlenose dolphin 82 can also perform long-range movements in this region (Silva et al., 2008; Dinis et al., 2016). We 83 investigated for the first time horizontal large-scale movements of this species between the 84 archipelagos of Madeira, Azores and the Canary Islands, i.e. within the biogeographical region 85 of Macaronesia, and with the Portuguese continental shelf, covering an area of more than 1600 $86000 \mathrm{Km} 2$. The present study aims to the better understanding of the bottlenose dolphin 87 connectivity among these remote oceanic archipelagos, and to help in this species' future 88 conservation and management efforts.

89

90

91

92

93

94

95

96

97

98

99

100

101

102

103

104

105

106

107

108

109

110

111

112

113

114

115

116

117

118

119

\section{Materials \& Methods}

\section{STUDY AREA}

The study area included the oceanic archipelagos of Madeira, Azores and the Canary Islands in the Macaronesia region, plus an adjacent coastal area along the Iberian Peninsula (Fig. 1). Macaronesia consists of island archipelagos located in the Northeast Atlantic Ocean, off the coasts of Europe and West Africa (Almada et al., 2013). It has a unique marine fauna, which has been influenced by West Africa, the Mediterranean Sea and continental western Europe (Floeter et al., 2007; Almada et al., 2013), making this region an ideal habitat for a high number of cetacean species (Pérez-Vallazza et al., 2008; Freitas et al. 2012; Silva et al., 2014; Alves et al., 2018b).

\section{PHOTO-IDENTIFICATION DATA}

Dolphin movements were determined through the cross-comparison of photo-identification catalogues held by eight organizations in Portugal and Spain (Table 1). The Madeira catalogue was compiled by Oceanic Observatory of Madeira (OOM) and comprised 363 individuals collected between 2004 and 2016, and sighted mainly off the south coast of Madeira. Two catalogues from the Azores were included, one containing 176 individuals from Pico and Faial islands collected between 2003 to 2007 compiled by Nova Atlantis Foundation, and a second one with 495 individuals from Pico, Faial, São Miguel and Terceira islands, collected between 20042016 compiled a through a long-term citizen science program focused on whale-wacthing touristic operations in the Azores, called MONICET (MONItoring CETaceans). A third set of raw data from the Azores (Pico and Faial islands), containing 201 photos, from which 42 individuals were identified by OOM, collected by a whale-watching company (Espaco Thalassa), between 2014 and 2016 was added. From the Canary Islands, four catalogues from two institutions and from different islands were used: one from La Gomera with 182 individuals (2004-2015); one from Tenerife with 110 individuals (2014); one from La Palma with 142 individuals (2010-2011 and 2015), all compiled by SECAC (Sociedad para el Estudio de los Cetáceos en el Archipiélago Canario), and one with 281 individuals (2001-2011), that included 
120 photos from La Gomera, El Hierro and La Palma, compiled by BIOECOMAC (Biodiversidad,

121 Ecología marina y Conservación de la Universidad de La Laguna), using their own data and data

122 from a local NGO called M.E.E.R. e.V.(Mammals, Encounters, Education and Research - La

123 Gomera). The catalogue from Sagres contained 359 individual photographed from 2001 until

1242016 and was compiled by the whale-watching company Mar Ilimitado.

125 The catalogues used, were built using different sources, ranging from whale watching operators

126 to research teams and independent photographers and were constructed by creating a dataset of

127 capture histories, using individual information taken by photographs (following Würsig and

128 Jefferson, 1990). Photographs were graded according to their level of focus, contrast, exposure

129 and angle of the dorsal fin; and level of distinctiveness of the individuals was graded according

130 to the number of nicks and notches present in the dorsal fin. Only good quality photos and

131 distinct and very distinct individuals were used in this analysis in order to enhance the reliability

132 of the matches (Urian et al. 2015). Whenever a match was found and confirmed, the same

133 identification number as that of the individual stored in the database was assigned, but, if there

134 were no match, a new identification number was attributed to that individual and it was added to

135 the catalogue as a new individual (Dinis et al. 2016). The matching procedure was conducted

136 through the comparison of natural markings like nicks and notches on the dorsal fin, and the

137 shape of the fin (Würsig and Würsig, 1977). In all the catalogues, with the exception of the one

138 made by BIOECOMAC, the comparison was conducted by the same researcher by naked eye,

139 and confirmed by a second experienced researcher. If doubts persisted, a third experienced

140 researcher would double-check. In the catalogue compiled by BIOECOMAC, dorsal fin images

141 were entered into a digital database using the software Darwin 2.0 (CEckerd College Dolphin

142 Research Group), a trailing edge contour was extracted, which was identifiable from both sides

143 (Auger-Méthé and Whitehead, 2007), and the software was used to assist the matching of

144 individual dolphins (Tobeña et al. 2014).

145

146

147 The Macaronesia database, containing only the individual matches, was compiled by comparing

148 the individual catalogues introduced in the previous section. The comparison was made

149 following the procedures described above, by naked eye, always by the same researcher. The

150 researcher graded all photographs according to their level of distinctiveness and quality, only

151 using photographs with good quality and individuals that were distinct and very distinct. When a

152 match was found, an identification code (the Macaronesia identification code) was created, for

153 that individual both pictures of the dolphin were added to the database and both locations were

154 indicated in the capture history dataset. Only dolphins seen in two or more archipelagos and

155 matches with $100 \%$ certainty, when confirmed by a second experience researcher, were included

156 in this database.

157

158

ASSOCIATIONS AND RESIDENCY IN MADEIRA ARCHIPELAGO

Peer] reviewing PDF | (2020:08:51663:2:0:NEW 9 Feb 2021) 
159 The study of the association patterns was made for Madeira archipelago data, including the

160

161

162

163

164

165

166

167

168

169

170

171

172

173

174

175

176

177

178

179

180

181

182

183

184

185

186

187

188

189

190

191

192

193

194

195

196

197

individuals that were seen in more than one archipelago. It aimed to investigate the residency pattern of these individuals in Madeira and their connectedness with the other dolphins identified in this archipelago. Individuals from the Madeira catalogue, seen in association with other individuals between 2004 and 2016 were used in this analysis. Associations between individuals were analyzed according to residency patterns established for this archipelago (Dinis et al., 2016). Residency patterns were assigned to individual dolphins based on their capture histories. The term 'resident' was used to designate dolphins that were seen regularly during the study period in the study area (during three seasons in a year and in more than two consecutive years), 'transient' dolphins were defined as those seen just once in the main area and dolphins seen more than once, but in non-consecutive years, were considered 'migrants'. A social network diagram was created using NetDraw 2.160 (Borgatti, 2002) to visualize individual association.

\section{Results}

\section{PHOTO-IDENTIFICATION ANALYSIS}

There were 26 dolphins with matches: 23 between Madeira and Canary Islands ( $\approx 500 \mathrm{Km}$ apart), and three individuals between the Azores and Madeira $(\approx 1000 \mathrm{Km}$ apart). No matches between the Canary Islands and the Azores were found. Likewise, none of the individuals were seen in all three archipelagos, nor between Madeira and Sagres (Fig.2). The 23 matches between Madeira and the Canary Islands (occurred on three of the four studied islands in the Canary Islands, mainly with El Hierro $(\mathrm{n}=6, \approx 570 \mathrm{Km})$ and La Palma $(\mathrm{n}=14, \approx 460 \mathrm{Km})$ (S1 Table). The results also showed back and forth movements made by Tt_MAC_8 and Tt_MAC_12, between Madeira and the Canary Islands, representing a round-trip of approximately $920 \mathrm{Km}$ (Fig.3). Moreover, two individuals were seen within the Canary Islands, and then off Madeira several years later: Tt_MAC_3 was sighted seven times intermittently off El Hierro in 2004, 2008, 2009, then was photographed off La Palma in 2010, and sighted two times off Madeira in 2014 and in 2016. Tt_MAC_4 was first seen off El Hierro in 2009, then sighted off the neighboring island of La Gomera in 2010, was observed again in El Hierro in 2010 and 2011, and eventually sighted off Madeira in 2015 (S1 Table). Four individuals (Tt_MAC_7, 11, 13 and 17) were sighted off La Palma on the same date (on 24th May 2011) and then sighted together off Madeira on 13th August 2011 with less than 3 months between re-sightings (Fig.4). Tt_MAC_9, 12, 14 and 15 were sighted in the same time frame and in the same locations (Table S1).

The three individuals seen first in the Azores and last off Madeira were sighted three (Tt_MAC_24), nine (Tt_MAC_25) and 10 (Tt_MAC_26) years apart. Tt_MAC_24 was seen in Pico island, which represents a distance to Madeira of approximately $1200 \mathrm{Km}$, while Tt_MAC_25 and 26 were sighted off São Miguel which represents a distance to Madeira of roughly $950 \mathrm{Km}$. No movements from Madeira to Azores were recorded (Fig.5). 
198 Tt_MAC_17 was photographed off La Palma and then off Madeira within 62 days, presenting

199

200

201

202

203

204

205

206

207

208

209

210

211

212

213

214

215

216

217

218

219

220

221

222

223

224

225

226

227

228

229

230

231

232

233

234

235

236

237

the minimum time interval that an individual travelled between two archipelagos, covering around $460 \mathrm{Km}$ within this timeframe.

\section{ASSOCIATIONS AND RESIDENCY IN MADEIRA ARCHIPELAGO}

The social network diagram (Fig 6) incorporated 332 individual dolphins, catalogued in Madeira archipelago, and presents three clusters grouped by residency patterns. Seventeen dolphins were seen both in the Canary Islands and in Madeira associated with all categories of residency patterns. Two dolphins seen both in Azores and Madeira (Tt_MAC_24 and 25) associated with migrant individuals seen both in Madeira and in the Canary Island (Tt_MAC_3 and 20), and the third (Tt_MAC_26) was seen in association with transient dolphins.

\section{Discussion}

This study shows that 26 bottlenose dolphins photo-identified off Madeira moved between, at least two Macaronesian archipelagos, demonstrating that this species' population covers wide areas in the NE Atlantic. These 26 individuals correspond to $7.1 \%$ of the 363 catalogued dolphins in the Madeira archipelago, similarly to what was found for UK and Irish waters (approximately 6\%, Robinson et al., 2012). Only a few studies described long-distance movements $(>1000 \mathrm{Km})$ of bottlenose dolphin around the world (e.g. Wood, 1998; Wells et al., 1999; Robinson et al., 2012), and none covered these three archipelagos of the Macaronesia region so far, thus this study expands our knowledge of the species in this area of the NE Atlantic. Previous examples of wider-scale movements based on photo-identified bottlenose dolphins come from Argentina (Würsig, 1978), Ireland (O’Brien et al., 2009), Mediterranean Sea (Gnone et al., 2011) and eastern North Pacific Ocean (Defran et al., 2006; Hwang et al., 2014). For example, off Argentina, one individual travelled $300 \mathrm{Km}$, while off the coast of Ireland, an individual travelled a distance as large as $650 \mathrm{Km}$. The distances reported here for the individuals that moved between Madeira and the Canary Islands are comparable to these ones, and if we consider the round-trip, the distance travelled is even larger, similar to the $965 \mathrm{Km}$ covered by a dolphin that travelled from Mexico to the USA, described by Hwang et al. (2014). The distance travelled by Tt_MAC_24 seen off Pico island as well as off Madeira Island, represents a distance of approximately $1200 \mathrm{Km}$, one of the highest distances recorded so far for this species. It comes closer to the $1277 \mathrm{Km}$ an individual travelled between UK and Ireland (Robinson et al., 2012).

The inshore waters of the oceanic archipelagos within the NE Atlantic waters offer a sheltered place where bottlenose dolphins can feed, when compared to the offshore waters nearby (Silva et al., 2008; Dinis et al., 2016). Possibly, when food resources are scarce, some individuals may travel longer distances to where similar, and more abundant food resources may be available. In less productive habitats such as oceanic waters, animals can be expected to have larger home ranges because there is a need to range further to find sufficient food (Silva et al., 2008; Bräger and Bräger, 2019 ). 
238 The back and forth movements we found demonstrate that at least some of the bottlenose 239 dolphins in Macaronesia have very large home ranges that include more than one archipelago.

240 One would expect that the dolphins prefer to travel comparably shorter distances because it

241 would imply less effort. This might explain the higher number of matches between the Madeira

242 archipelago and the Canary Islands as compared to the greater distance between the Azores and

243 the Canaries. In addition, Madeira archipelago and the Canary Islands share many

244 biogeographic, and likely also oceanographic characteristics. Freitas and colleagues (2019)

245 speculate that Madeira and the Canary Islands should constitute a formal biogeographic unit

246 when referring to the high number of shared endemic marine species. The same study affirms

247 that genetic interchange (e.g. larvae dispersion, colonization events) occur much more frequently

248 between these two archipelagos than with other areas of Macaronesia.

249 Although we could not determine the sex of the dolphins seen in more than one archipelago, for

250 male bottlenose dolphins, long-distance movements could also serve to get access to receptive

251 females outside their own population. I.e., young adult males could be driven to seek for females,

252 as described for Indo-pacific bottlenose dolphin (Tursiops aduncus) in Shark Bay, Australia

253 (Connor, Smolker \& Richards, 1992), and thereby also increasing gene flow between

254 populations. In this way, population viability could be improved and genetic differences within

255 the NE Atlantic bottlenose dolphin populations may perhaps decrease, as confirmed by a study

256 that compared individuals from the Madeira and Azores archipelagos (Querouil et al., 2007).

257 Tobeña and colleagues (2014), in a study reporting inter-islands movements within the Canary

258 Islands, described two individuals that were seen over a long period of time (three and four

259

260

261

262

263

264

265 years). These two individuals are Tt_MAC_3 and 4 in this study, suggesting that even individuals that were considered resident in an area or having a high degree of site fidelity may undertake long-range movements from time to time. Another cross-Macaronesian study (Alves et al., 2018a) reported a group of five socially related short-finned pilot whales with strong site fidelity to Madeira which made a round trip to the Azores archipelago, covering approximately $2000 \mathrm{Km}$, highlighting the importance of caution when assigning residency patterns to smaller

266 areas in oceanic waters. Similarly, in the study of long-range movements of bottlenose dolphins

267 (Robinson et al., 2012), the far ranging individuals had been considered to belong to discrete resident populations in the UK and Ireland.

268 Four individuals (Tt_MAC 7, 11, 13, 17) were seen together off La Palma and were encountered 269 thereafter in Madeira (Fig.4). Our results also showed that other Macaronesian individuals

270

271

272

273

274

275

276

277 (Tt_MAC_9, 12, 14 and 15) were documented during the same period in both archipelagos, indicating stable social association, which may persist during, or even favor, long-range oceanic journeys.

Bottlenose dolphins' social structure vary between locations, and even individuals from the same community may behave differently (Gowans, 2019; Genov et al. 2019). Our network analysis for the Madeira archipelago revealed that the Macaronesian bottlenose dolphins were seen with transients, migrants and resident dolphins, including one resident that has a high level of centrality (Dinis et al., 2016). This indicates that some far-ranging dolphins are connected to 
278 individuals that play a central role for connectivity of local network as social brokers (Lusseau \& 279 Newman, 2004). Individuals exhibiting extended home ranges can have a fundamental role, 280 contributing to a genetic variability in oceanic dolphin communities, which otherwise would be 281 genetically isolated (Louis et al., 2014).

282 The minimum period of time between the re-captures in different archipelagos (Canary Islands to 283 Madeira) was 62 days. Satellite-monitored movements of an individual bottlenose dolphin off 284 Florida showed that the dolphin moved $581 \mathrm{Km}$ in 25 days (Mate et al., 1995). In Japan, one 285 tagged bottlenose dolphin travelled about $604 \mathrm{Km}$ in 18 days (Tanaka, 1987). Therefore, the time 286 period documented in this study is comparatively long, but the actual time it took the dolphins to

287

288

289

290

291

292

293

294

295

296

297

298

299

300

301

302

303

304

305

306

307

308

309

310

311

312

313

314

315

316

317 cover the distance from one archipelago to the other remains unknown. In one study using satellite telemetry (Klatsky, Wells \& Sweeney, 2007), the authors determined a mean travel distance of $28.3 \mathrm{Km} /$ day for three offshore bottlenose dolphins, which suggests that the dolphins reported here could have covered the distance within a time period well below 62 days. Alternatively, they may also have travelled a much longer distance within those 2 months. The fact that we did not find any match between the Madeira archipelago and the Portuguese continental shelf should not exclude the assumption that some individuals may undertake these even longer trips. A previous study on bottlenose dolphin populations of the NE Atlantic (Louis et al., 2014) found no genetic structure between the Azores archipelago and individuals from several parts of the NE Atlantic, including the shelf-edge.

Connectivity studies can be a monitoring tool when assessing ranging patterns over wider areas, as has been regularly made for large whales (e.g. Robbins et al., 2011; Bertulli et al., 2013; Carpinelli et al., 2014). We now know that at least some bottlenose dolphins perform extreme mobility throughout the Macaronesia region. This has multiple implications for conservation and management efforts designed for this species: Firstly, management units may not be separable and their connectivity must be taken into account e.g. when establishing marine protected areas (MPAs). Connected populations will have to be considered coherently within conservation frameworks such as the European Union Habitats \& Species Directive (HD). Bottlenose dolphins inhabiting Macaronesia waters are, as in other places, subject to many threats like fisheries interaction (by-catch), overfishing, pollution, vessel strikes, stress caused by human recreational activities such as whale-watching and climate change, among others (Reeves, 2018). In the Macaronesia region a large number of marine protected areas were designed to protect bottlenose dolphins, but with different levels of protection (Hoyt, 2011). Some of these are SACs (Special Area of Conservation) designated as part of the Natura 2000 network under the European Union HD. Most marine SACs thereby only cover coastal areas, rather than reaching offshore. While the establishment of MPAs is a step forward to protect bottlenose dolphins (Hoyt, 2011; Silva et al., 2012) in this region, more has to be done in terms of mitigations measures, as many of the established SACs still lack management plans. In the Azores, it has been demonstrated that the established areas are not sufficient mainly because they are not covering the complete home range of the dolphins (Silva et al., 2012). The same applies to the Canary Islands and to Madeira archipelago. Our results confirm that the bottlenose dolphins' home range in Macaronesia

Peer] reviewing PDF | (2020:08:51663:2:0:NEW 9 Feb 2021) 
318 includes more than one archipelago and the offshore waters around them. This means that SACs

319 should be expanded to include offshore waters allowing protection measures to be more

320 effective. Such an expansion would have positive side effect for other highly mobile species, like

321 the short-finned pilot whale, that are known to use this area widely, too (Alves et al., 2019).

322

323

\section{Conclusions}

324

325

326

327

328

329

330

331

332

333

334

335

336

337

338

339

340

341

342

343

345

346

347

348

349

350

351

352

353

354

355

356

357

358
This study provides first evidence of large-scale connectivity of bottlenose dolphin communities between Macaronesia archipelagos, highlighting the strength of combining photo-identification catalogues from different areas, and can be seen as a first step to review the established boundaries of the existing MPAs (SACs) for this species in Macaronesia. This will require a considerable effort, because there are three different autonomous communities (Madeira, Azores and Canary Islands) involved, belonging to two EU member states (Portugal and Spain). Nevertheless, it would correspond to an adaptive and ecosystem-based management approach and serve the coherent protection of the species across borders - all aspects that the EU HD strives to achieve.

\section{Acknowledgements}

We would to thank to all the people and organizations involved in the collection of photographic and sighting data over the years. In the Azores the online MONICET platform (www.monicet.net) has the collaboration of the whale-watching companies Terra Azul - Azores Islands Whales and Dolphins, Picos de Aventura - Animação e Lazer Lda., Azores Experiences - Whale Watching \& Jeep Tours, Ocean Emotion Azores Whale Watching, SeaColors Expeditions and Futurismo-Azores WhaleWatching. In Madeira, we thank to whale-watching operators Ventura, H2O-Madeira, Seaborn, VMT Madeira and Lobosonda, and in the Canary Island, to whale-watching operator

OCEANO Gomera and the NGO M.E.E.R.eV.

\section{References}

Almada VC, Toledo JF, Brito A, Levy A, Floeter SR, Robalo JI, Martins J, Almada F. Complex origins of the Lusitania biogeographic province and northeastern Atlantic fishes. Front Biogeogr. 2013;5: 20-28. doi: 10.21425/F5FBG14493

Alves F, Alessandrini A, Fernandez M, Hartman KL, Dinis A. Home sweet home? Wide-raging movements of socially stable resident delphinids (Globicephala macrorhynchus). Scientia insularum. 2018a; doi: 10.25145/j.SI.2018.01.004

Alves F, Alessandrini A, Servidio A, Mendonça AS, Hartman KL, Prieto R, Berrow S, Magalhães S, Steiner L, Santos R, Ferreira R, Marrero J, Ritter F, Dinis A, Martín V, Silva M, 
359

360

361

362

363

364

365

366

367

368

369

370

371

372

373

374

375

376

377

378

379

380

381

382

383

384

385

386

387

388

389

390

391

392

393

394

395

396

397

398

Aguilar N. Complex biogeographical patterns support an ecological connectivity network of a large marine predator in the north-east Atlantic. Divers Distrib. 2019; 25: 269-284. doi:10.1111/ddi.12848

Alves F, Ferreira R, Fernandes M, Halicka Z, Dias L, Dinis A. Analysis of occurrence patterns and biological factors of cetaceans based on long-term and fine-scale data from platforms of opportunity: Madeira Island as a case study. Mar Ecol. 2018b; 39, 2: e12499.doi.org/10.1111/maec.12499.10.1111/maec.12499

Auger-Méthé M, Whitehead $\mathrm{H}$. The use of natural markings in studies of long-finned pilot whale (Globicephala melas). Mar Mamm Sci. 2007; 23, 77-93. https://doi. org/10.1111/j.17487692.2006.00090.x

Bearzi G, Bonizzoni S, Gonzalvo J. Mid-distance movements of common bottlenose dolphins in the coastal waters of Greece. J Ethol. 2011; 29, 369-374.doi.org/10.1007/s10164-010-0245-x Borgatti SP. NetDraw: Graph visualization software. Harvard, MA: Analytic Technologies, 2002.

Bertulli CG, Rasmussen MH, Tetley MJ. Photo-identification rate and wide scale movement of common minke whales (Balaenoptera acutorostrata) in the coastal waters of Faxaflói and Skjálfandi Bays, Iceland. Journ of Cetacean Res and Manag. 2013; 13, 39-45.

Bräger S, Bräger Z. Movement Patterns of Odontocetes Through Space and Time. In Würsig, B, editor. Ethology and Behavioral Ecology of Odontocetes.. Springer; 2019.

Carpinelli E, Gauffier P, Verborgh P, Airoldi S, David L, Di-Meglio N, Cañadas A, Frantzis A, Rendell L, Lewis T, Mussi B, Pace DS, de Stephanis R. Assessing sperm whale (Physeter macrocephalus) movements within the western Mediterranean Sea through photo-identification. Aquat Conserv Mar Freshwat Ecosyst. 2014; 24(Suppl 1):23-30. doi:org/10.1002/aqc.2446

Connor RC, Smolker RA, Richards AF. Two levels of alliance formation among male bottlenose dolphins (Tursiops sp.). Proc Natl Acad Sci U S A. 1992; 89(3), 987-990. doi: 10.1073/pnas.89.3.987

Defran RH, Weller DW, Kelly DL, Espinosa MA. Range characteristics of Pacific coast bottlenose dolphins (Tursiops truncatus) in the Southern California Bight. Mar Mamm Sci. 1999; 15(2), 381-393. doi: 10.1111/j.1748-7692.1999.tb00808.x

Dinis A, Alves F, Nicolau C, Ribeiro C, Kaufmann M, Cañadas A, Freitas L. Bottlenose dolphin Tursiops truncatus group dynamics, site fidelity, residency and movement patterns in the 
399 Madeira Archipelago (North-East Atlantic). Afr J Ma. Sci. 2016; 38(2), 151-160.

400 doi.org/10.2989/1814232X.2016.1167780

401

402

403

404

405

406

407

408

409

410

411

412

413

414

415

416

417

418

419

420

421

422

423

424

425

426

427

428

429

430

431

432

433

434

435

436

437

438

Floeter SR, Rocha LA, Robertson DR, Joyeux JC, Smith-Vaniz WF, Wirtz P, Edwards AJ, Barreiros JP, Ferreira CEL, Gasparini JL, Brito A, Falcón JM, Bowen BW, Bernardi G. Atlantic reef fish biogeography and evolution. J Biogeogr. 2018; 35: 22-47. doi.org/10.1111/j.13652699.2007.01790.x

Freitas L, Dinis A, Nicolau C, Ribeiro C, Alves F. New records of cetacean species for Madeira Archipelago with an updated checklist. Bol Mus Mun Fun. 2012; 62(334): 25-43.

Freitas R, Romeiras M, Silva L, Cordeiro R, Madeira P, González JA, Wirtz P, Falcón JM, Brito A, Floeter SR, Afonso P, Porteiro F, Vieira-Rodríguez MA, Neto AI, Haroun R, Farminhão JNM, Rebelo AC, Baptista L, Melo CS, Martínez A, Núñez J, Berning B, Johnson ME, Ávila SP. Restructuring of the 'Macaronesia' biogeographic unit: A marine multi-taxon biogeographical approach. Sci Rep. 2019; 9, 15792. doi.org/10.1038/s41598-019-51786-6

Genov T, Centrih T, Kotnjek P, Hace A. Behavioural and temporal partitioning of dolphin social groups in the northern Adriatic Sea. Mar Biol. 2019; 166(1), 11.

Gnone G, Bellingeri M, Dhermain F, Dupraz F, Nuti S, Bedocchi, D, Moulins A, Rosso M, Alessi J, McCrea RS, Azzelino A, Airoldi S, Portunato N, Laran S, David L, Di Meglio N, Bonelli P, Montesi G, Trucchi R, Fossa F, Wurtz M. Distribution, abundance, and movements of the bottlenose dolphin (Tursiops truncatus) in the Pelagos Sanctuary MPA (north-west Mediterranean Sea). Aquat Conserv 2011; 21(4), 372-388.

Gowans S. Grouping Behaviors of Dolphins and Other Toothed Whales. In Würsig B. editor. Ethology and Behavioral Ecology of Odontocetes. Springer; 2019.

Hoyt E. Marine Protected Areas for Whales, Dolphins and Porpoises: A world handbook for cetacean habitat conservation and planning. 2 nd ed. Routledge; 2011.

Hwang A, Defran R, Bearzi M, Maldini D, Saylan CA, Lang, AR, Dudzik KJ, Guzòn-Zatarain OR, Kelly DL, Weller DW . Coastal range and movements of common bottlenose dolphins off California and Baja California, Mexico. Bulletin of the Southern California Academy of Sciences. 2014; vol. 113, no. 1. https://doi.org/10.3160/0038-3872-113.1.1

Klatsky, LJ, Wells, RS, Sweeney, JC. Offshore Bottlenose Dolphins (Tursiops truncatus): Movement and Dive Behavior Near the Bermuda Pedestal. J Mammal, 2007; 88(1): 59-66. doi.org/10.1644/05-MAMM-A-365R1.1

Peer] reviewing PDF | (2020:08:51663:2:0:NEW 9 Feb 2021) 
439

440

441

442

443

444

445

446

447

448

449

450

451

452

453

454

455

456

457

458

459

460

461

462

463

464

465

466

467

468

469

470

471

472

473

474

475

476

477

478
Louis M, Viricel A, Lucas T, Peltier H, Alfonsi E, Berrow S, Brownlow A, Covelo P, Dabin W, Deaville R, de Stephanis R, Gally F, Gauffier P, Penrose R, Silva MA, Guinet C, Simon-Bouhet B. Habitat-driven population structure of bottlenose dolphins, Tursiops truncatus, in the NorthEast Atlantic. Mol Ecol. 2014; 23 (4), 857-874. doi.org/10.1111/mec.12653

Lusseau D, Newman MEJ. Identifying the role that animals play in their social networks. Proc R Soc Lond B. 2004; (Suppl) 271:S477-S481. doi: 10.1098/rsbl.2004.0225

Mate B, Rossbach KA, Nieukirk SL, Wells RS, Irvine AB, Scott MD, Read AJ. Satellitemonitored movements and dive behavior of a bottlenose dolphin (Tursiops truncatus) in Tampa Bay, Florida. Mar Mamm Sci. 1995; 11:452-463. doi.org/10.1111/j.1748-7692.1995.tb00669.x

O’Brien JM, Berrow SD, Ryan C, McGrath D, O’Connor I, Pesante G, Burrows G, Massett N, Klötzer V, Whooley P. A note on long-distance matches of bottlenose dolphins (Tursiops truncatus) around the Irish coast using photo-identification. J Cetacean Res Manag. 2009; 11(1), 71-76

Oudejans MG, Visser F, Englund A, Rogan E, Ingram SN. Evidence for distinct coastal and offshore communities of bottlenose dolphins in the north east Atlantic [published correction appears in PLoS One. 2015; 10 (5):e0128259]. doi:10.1371/journal.pone.0122668

Pérez-Vallazza C, Álvarez-Vázquez R, Cardona L, Pintado C, Hernández-Brito J. Cetacean diversity at the west coast of La Palma Island (Canary Islands). J Mar Biol Assoc UK. 2008; 88(6), 1289-1296. doi: 10.1017/S0025315408001239

Querouil S, Silva MA, Freitas L, Prieto R, Magalhães S, Dinis A, Alves F, Matos J, Mendonça D, Hammond PS, Santos RS. High gene flow in oceanic bottlenose dolphins (Tursiops truncatus) of the North Atlantic. Conserv Genet. 2007; 8(6), 1405. doi.org/10.1007/s10592-007-9291-5

Reeves, RR. Conservation In: Perrin WF, Würsig B, Thewissen JGM and Kovacs KM, editors. Encyclopedia of marine mammals, third ed. Academic Press; 2018. pp. 361-364.

Reynolds JE, Wells RS, Eide SD. The bottlenose dolphin: biology and conservation. Gainesville: University Press of Florida; 2000.

Robbins J, Rosa LD, Allen JM, Mattila DK, Secchi ER, Friedlaender AS, Stevick PT, Nowacek DP, Steel D. Return movement of a humpback whale between the Antarctic Peninsula and American Samoa: A seasonal migration record. Endanger Species Res 2011; 13, 117-121. doi: $10.3354 /$ esr00328

Peer] reviewing PDF | (2020:08:51663:2:0:NEW 9 Feb 2021) 
479

480

481

482

483

484

485

486

487

488

489

490

491

492

493

494

495

496

497

498

499

500

501

502

503

504

505

506

507

508

509

510

511

512

513

514

515

516

517

518

Robinson KP, O'Brien J, Berrow S, Cheney B, Costa M, Elsfield SM. Discrete or not so discrete: long distance movements by coastal bottlenose dolphins in UK and Irish waters. J Cetacean Res Manag. 2012; 12(3):365-371

Shane SH, Wells RS, Würsig B. Ecology, behavior and social organization of the bottlenose dolphin: a review. Mar Mamm Sci 1986; 2, 34-63. doi:10.1111/j.1748-7692.1986.tb00026.x

Silva MA, Prieto R, Cascão I, Seabra MI, Machete M, Baumgartner MF, Santo RS. Spatial and temporal distribution of cetaceans in the mid-Atlantic waters around the Azores, Mar Biol Res. 2014; 10:2, 123-137, doi: 10.1080/17451000.2013.793814

Silva MA, Prieto R, Magalhães S, Seabra MI, Machete M, Hammond PS. Incorporating information on bottlenose dolphin distribution into marine protected area design. Aquat Conserv. 2012; 22(1), 122-133. doi.org/10.1002/aqc.1243.

Silva MA, Prieto R, Magalhães S, Seabra MI, Santos RS, Hammond PS. Ranging patterns of bottlenose dolphins living in oceanic waters: implications for population structure. Mar Biol. 2008; 156(2), 179.

Tanaka, S. Satellite radio tracking of bottlenose dolphins Tursiops truncatus. Nippon Suisan Gakkaishi.1987; 53:1327-1338. doi.org/10.2331/suisan.53.1327

Tobeña M, Escánez A, Rodríguez Y, López C, Ritter F, Aguilar N. Inter-island movements of common bottlenose dolphins Tursiops truncatus among the Canary Islands: online catalogues and implications for conservation and management. Afr J Ma. Sci. 2014; 36(1), 137-141. doi: 10.2989/1814232X.2013.873738

Urian K, Gorgone A, Read A, Balmer B, Wells RS, Berggren P, Durban J, Eguchi T, Rayment W, Hammond PS. Recommendations for photo-identification methods used in capture-recapture models with cetaceans. Mar Mamm Sci. 2015; 31, 298-321. https://doi.org/10.1111/ mms.12141

Wells R, Rhinehart HL, Cunningham-Smith P, Whaley J, Baran M, Koberna C, Costa DP. Long distance offshore movements of bottlenose dolphins. Mar Mamm Sci. 1999; 15 (4), 1098-1114. doi.org/10.1111/j.1748-7692.1999.tb00879.x

Wells RS, Scott MD. Common Bottlenose dolphin (Tursiops truncatus). In: Perrin WF, Würsig B, Thewissen JGM and Kovacs KM, editors. Encyclopedia of marine mammals, third ed. Academic Press; 2018. pp. 361-364.

Peer] reviewing PDF | (2020:08:51663:2:0:NEW 9 Feb 2021) 
519 Wood CJ. Movement of bottlenose dolphins around the south-west coast of Britain. J Zool.

520 1998; 246(2), 155-163. doi.org/10.1111/j.1469-7998.1998.tb00144.x

521

522 Würsig B. Occurrence and group organization of Atlantic bottlenose porpoises (Tursiops

523 truncatus) in an Argentine bay. The Biological Bulletin, 1978; 154(2), 348-359.

524

525 Würsig B, Jefferson T. Methods of photo-identification for small cetaceans. In Hammond P.S., 526 Mizroch S.A. and Donovan G.P. (eds) Individual recognition of cetaceans: use of photo-

527 identification and other techniques to estimate population parameters. Report of the International

528 Whaling Commission, special issue 12, 1990; Cambridge: International Whaling Commission, 529 pp. $43-52$.

530

531 Würsig B, Würsig M. The photographic determination of group size, composition, and stability 532 of coastal porpoises (Tursiops truncatus). Science, 1977; 198(4318), 755-756. doi:

$53310.1126 /$ science.198.4318.755

534

535 


\section{Table $\mathbf{1}$ (on next page)}

Summary of the photo-identification data used in this study 
1 Table 1. Summary of the photo-identification data used in this study.

\begin{tabular}{|c|c|c|c|}
\hline $\begin{array}{l}\text { Number of } \\
\text { individual } \\
\text { dolphins }\end{array}$ & Source & Period & Location \\
\hline 363 & $\begin{array}{l}\text { Oceanic Observatory of Madeira } \\
\text { (OOM) }\end{array}$ & 2004-2016 & Madeira island \\
\hline 176 & Nova Atlantis Foundation & $2003-2007$ & Pico (Azores) \\
\hline 495 & $\begin{array}{l}\text { MONICET Project-University of } \\
\text { Azores }\end{array}$ & 2004-2016 & $\begin{array}{l}\text { Pico, Faial, São Miguel and Terceira } \\
\text { (Azores) }\end{array}$ \\
\hline 42 & Espaço Thalassa & 2014-2016 & Pico and Faial (Azores) \\
\hline 182 & SECAC & $2004-2015$ & La Gomera (Canary Islands) \\
\hline 110 & SECAC & 2014 & Tenerife (Canary Islands) \\
\hline 142 & SECAC & $2010-2011$ & La Palma (Canary islands) \\
\hline 281 & $\begin{array}{l}\text { BIOECOMAC-University of La } \\
\text { Laguna/NGO MEER e.V. }\end{array}$ & 2001-2011 & $\begin{array}{l}\text { La Palma, La Gomera and Tenerife } \\
\text { (Canary islands) }\end{array}$ \\
\hline 359 & Mar Ilimitado & $2007-2015$ & Sagres \\
\hline
\end{tabular}


Figure 1

Map showing the study area

(A) Sagres, (B) Azores, (C) Madeira, (D) Canary Islands (extracted from Natural Earth:

https://www.naturalearthdata.com/) 


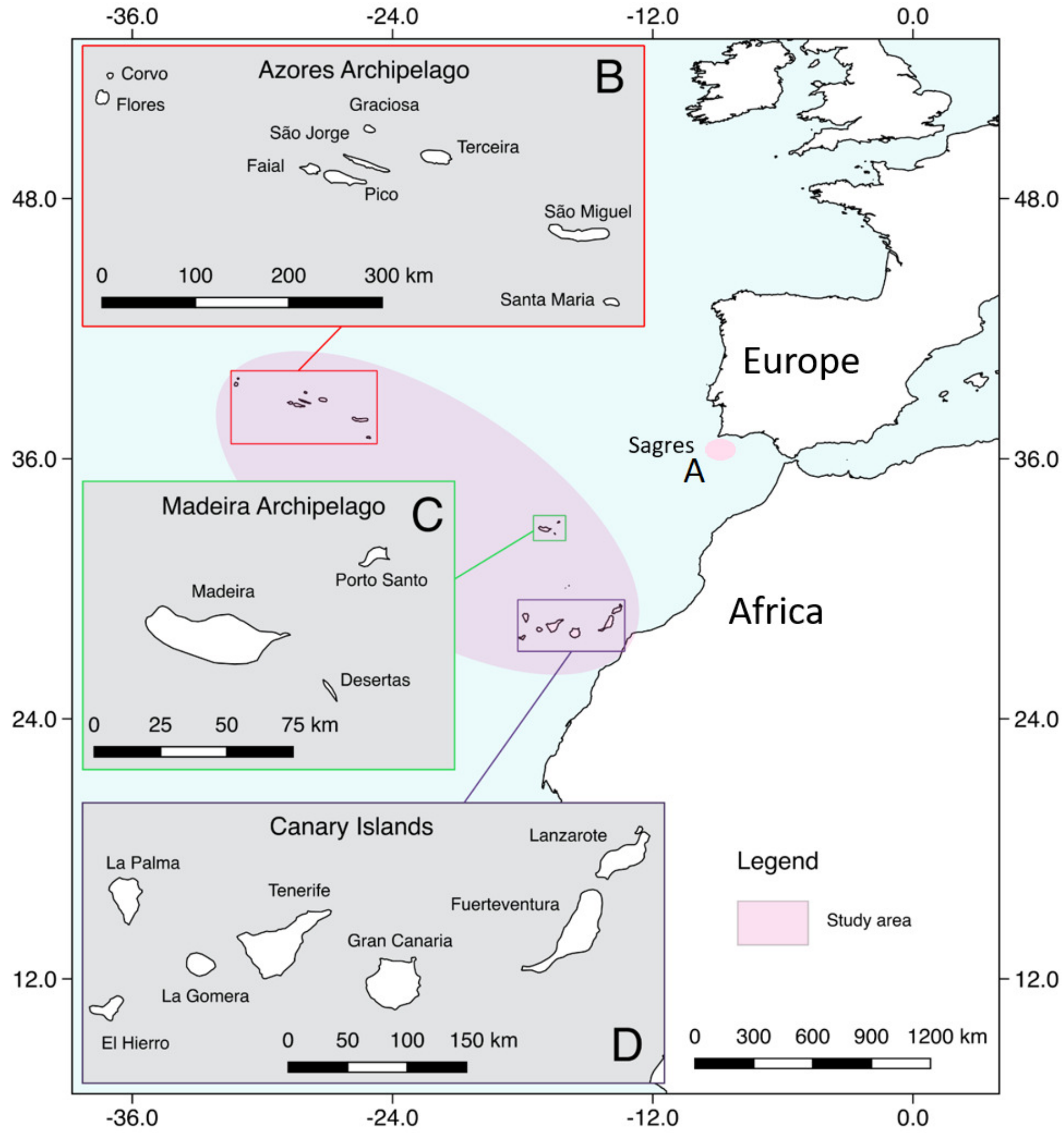


Figure 2

Number of individuals in the catalogues and the number of individuals with matches, distributed by areas.

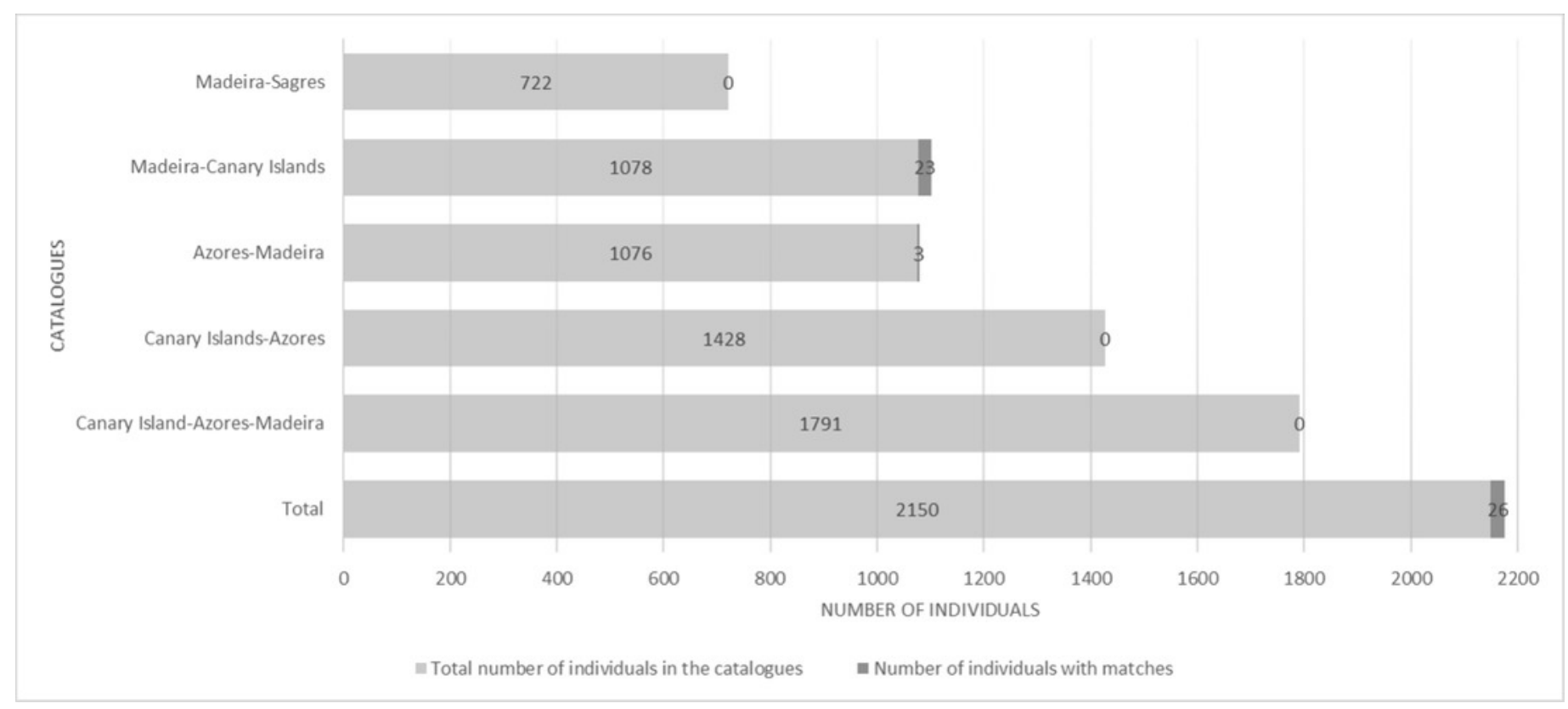


Figure 3

Map showing the two-way movements of two bottlenose dolphins between Madeira Island and La Palma, in the Canary Islands (round-trip of $\approx 920 \mathrm{Km}$ ).

The dots are just figurative and do not reflect the exact location of the dolphins. Illustration by E. Berninsone $\odot$ ARDITI.

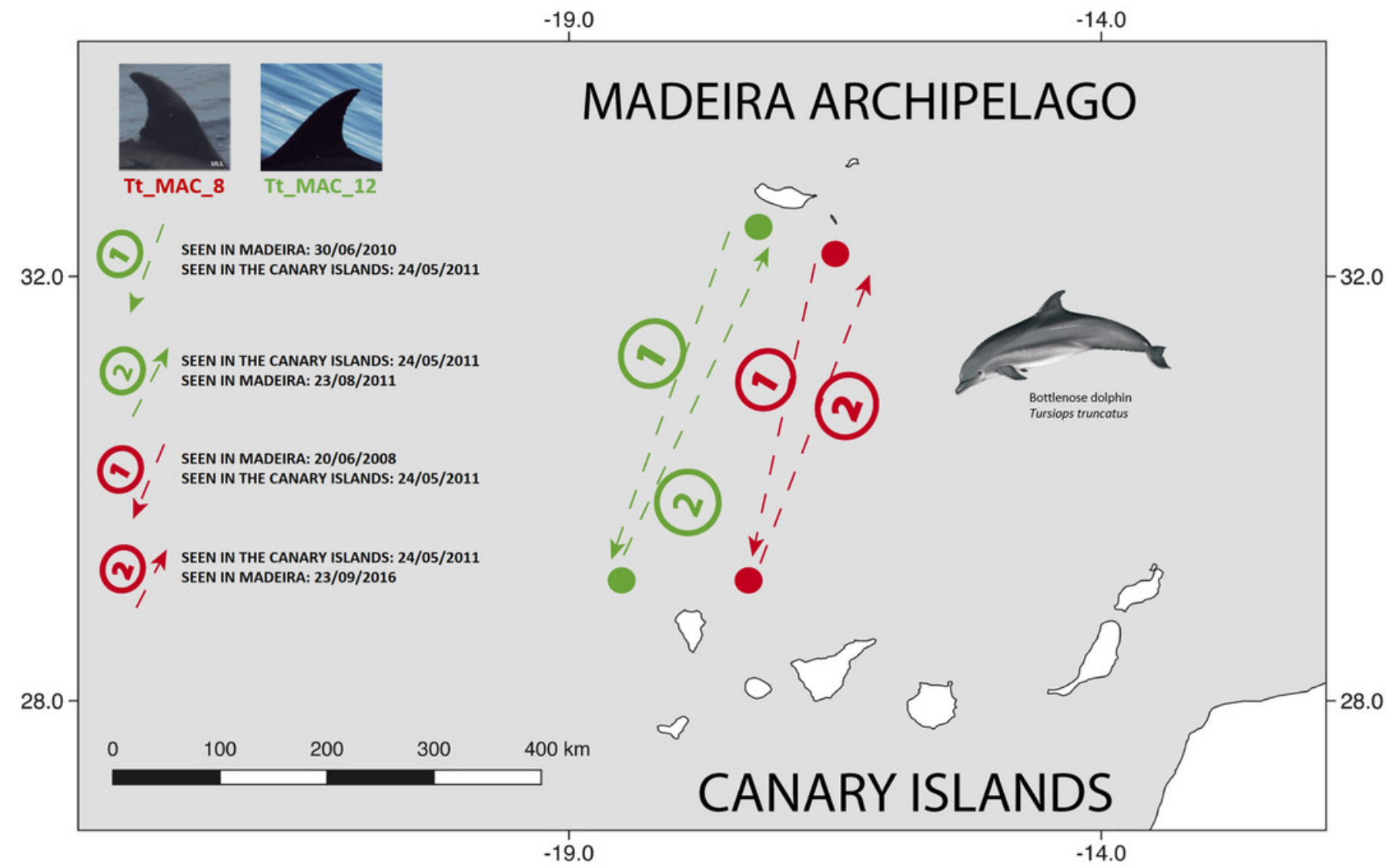


Figure 4

Map showing the movement of four bottlenose dolphins between the island of La Palma, in the Canary Islands and Madeira $(\approx 500 \mathrm{Km}$ ).

The dots are just figurative and do not reflect the exact location of the dolphins. Illustration by E. Berninsone $\odot$ ARDITI.

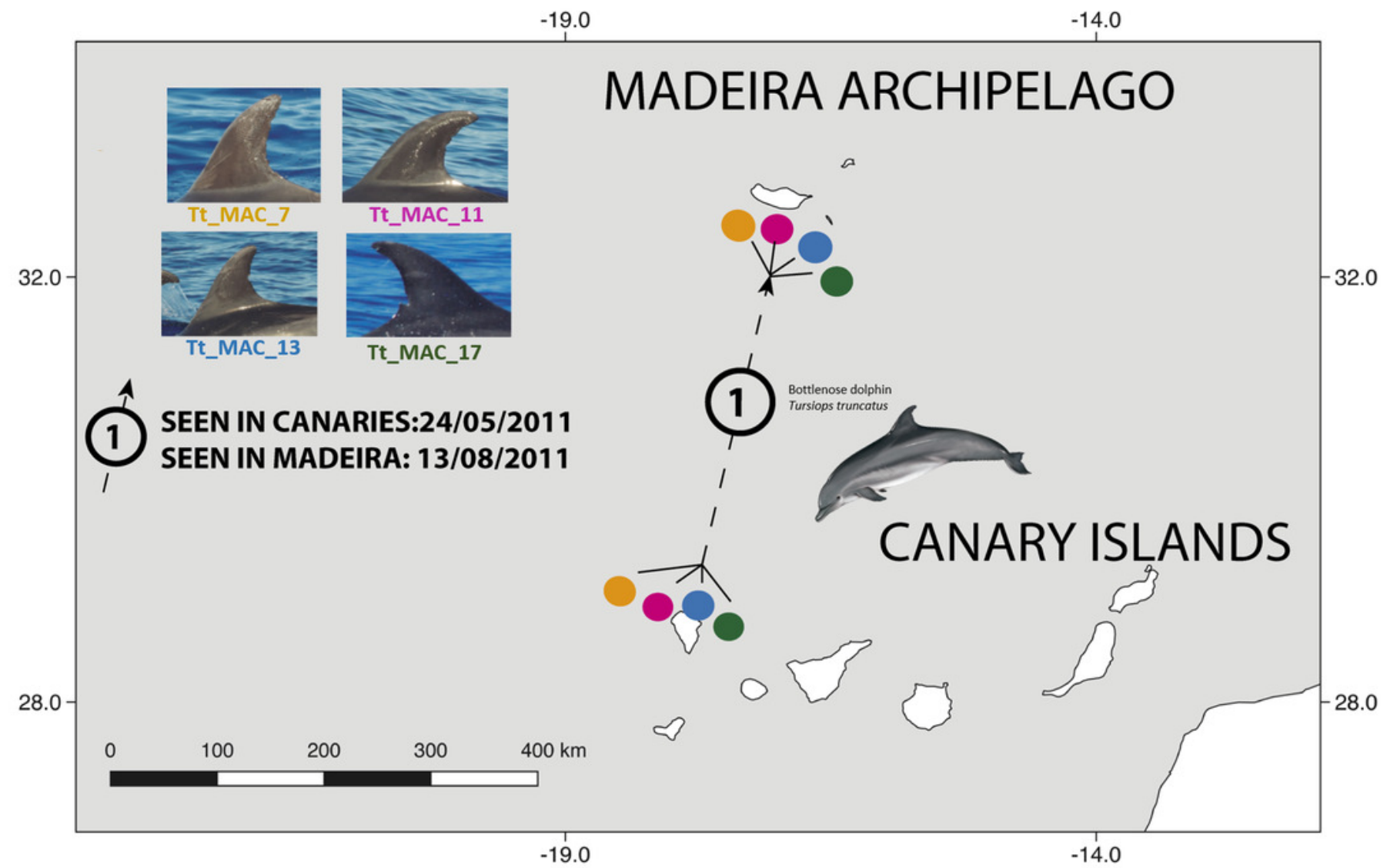




\section{Figure 5}

Map showing the movement of three bottlenose dolphins between the Azores (Pico and São Miguel islands), and Madeira archipelagos ( $\approx 1000 \mathrm{Km}$ )

The dots are just figurative and do not reflect the exact location of the dolphins. Illustration by E. Berninsone $\odot$ ARDITI.

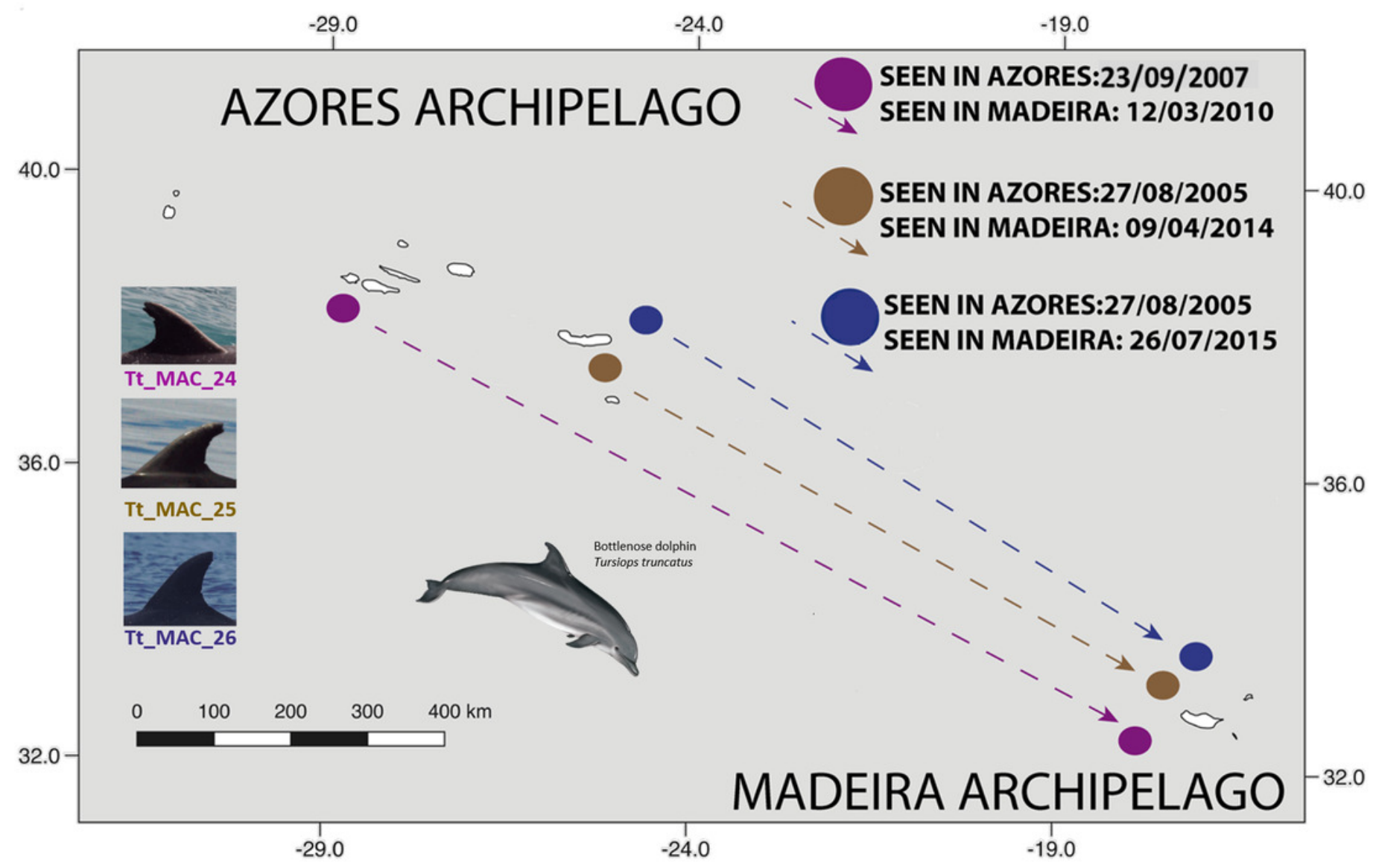




\section{Figure 6}

Social network diagram illustrating the associations between the dolphins with different residency patterns identified in Madeira, and the 20 dolphins seen in association in more than one archipelago.

Individual dolphins are represented by nodes and associations by the lines between nodes. Nodes color and shape indicates the archipelago of capture and residency pattern in Madeira archipelago.

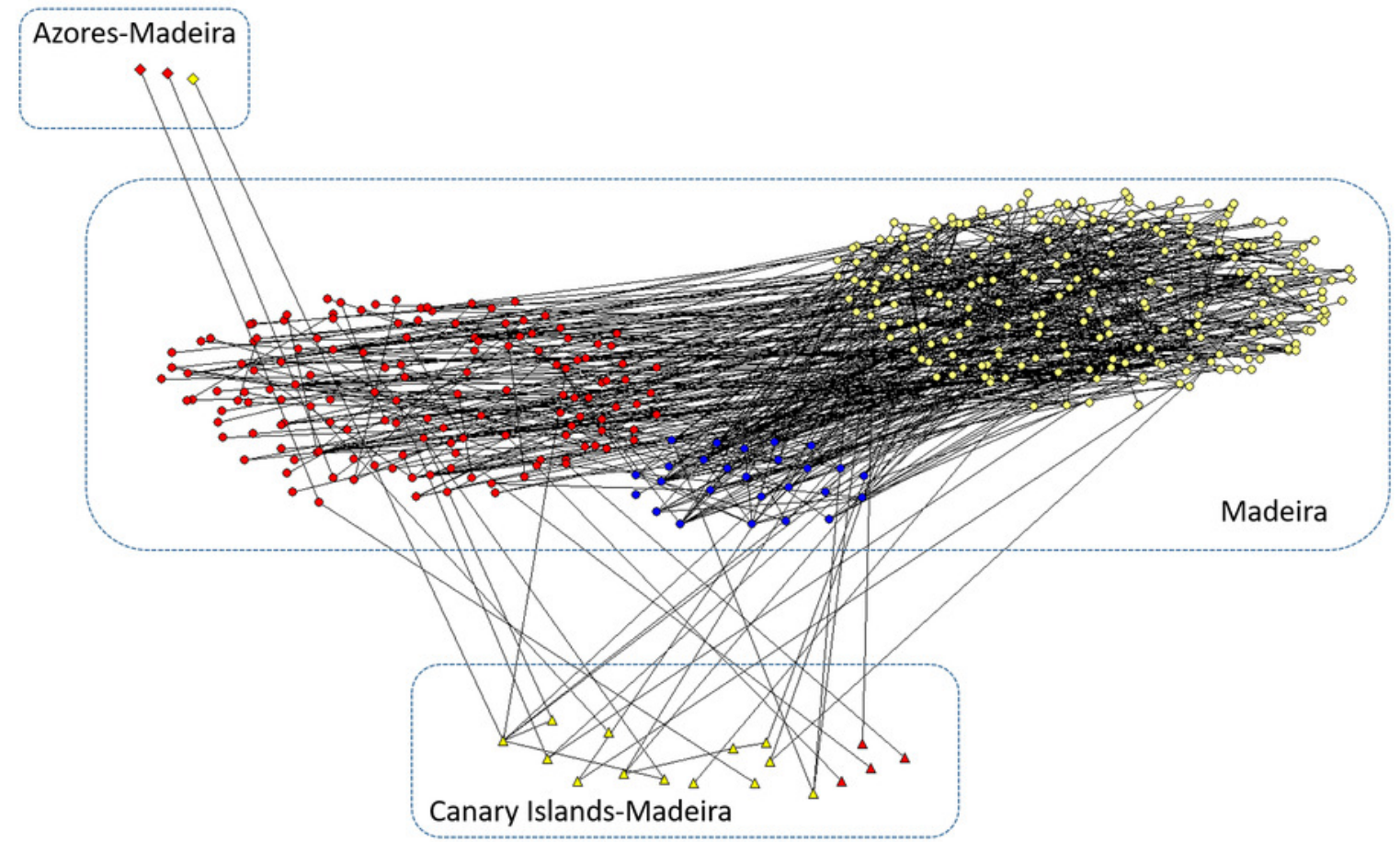

